Volume 11

Issue 1 Information and Communications

Technologies in Mass Atrocities Research and

Article 12

Response

$5-2017$

\title{
Book Review: The Betrayal: The Nuremberg Trials and German Divergence
}

Anton Weiss-Wendt

The Norwegian Holocaust Center, Oslo

Follow this and additional works at: https://digitalcommons.usf.edu/gsp

\section{Recommended Citation}

Weiss-Wendt, Anton (2017) "Book Review: The Betrayal: The Nuremberg Trials and German Divergence," Genocide Studies and Prevention: An International Journal: Vol. 11: Iss. 1: 107-109.

DOI:

http://doi.org/10.5038/1911-9933.11.1.1474

Available at: https://digitalcommons.usf.edu/gsp/vol11/iss1/12

This Book Review is brought to you for free and open access by the Open Access Journals at Digital Commons @ University of South Florida. It has been accepted for inclusion in Genocide Studies and Prevention: An International Journal by an authorized editor of Digital Commons @ University of South Florida. For more information, please contact digitalcommons@usf.edu. 
Book Review: The Betrayal: The Nuremberg Trials and German Divergence

\author{
Anton Weiss-Wendt \\ The Norwegian Holocaust Center \\ Oslo, Norway
}

The Betrayal: The Nuremberg Trials and German Divergence

Kim Christian Priemel

Oxford, Oxford University Press, 2016

481 Pages; Price: £65 Hardcover

Reviewed by Anton Weiss-Wendt

The Norwegian Holocaust Center, Oslo

Books on the Nuremberg trials are many, and Kim Priemel's The Betrayal is one of the most ambitious. What makes Priemel's study stand out is the scope of research, the breadth of analysis, and a well-defined thesis. What Priemel attempts in a single monograph is quite impressive. He assesses judicial proceedings of fifteen interrelated trials between 1945 and 1949 involving a total of 205 defendants. The transcript of the International Military Tribunal at Nuremberg (IMT) alone takes up 16,793 pages, plus the 4,600 prosecution exhibits. The subsequent twelve trials (NMT) left as significant a paper trail: 135,000 pages of transcript and more than 185,000 pages of trial evidence. Not to stop at trial proceedings, numerous memoirs, and scholarly publications, Priemel has done research in forty-four (!) different archives and research libraries for his book. What scholars and college students would probably appreciate most about Priemel's study is his ability to weave all the tribunals into a single, uninterrupted narrative.

The four countries occupying the prosecution stand - the United States, the Soviet Union, the United Kingdom, and France-arrived at IMT with different legal backgrounds and political agendas. That alone makes it fairly difficult construing a single overarching thesis, which would also cover the subsequent trials. Priemel believes he succeeded at that by developing a discourse on German divergence. According to Priemel, the Allies essentially determined that Germany as a nation was redeemable. This notion comes from a broader intellectual discussion whether Germany belongs to Western Civilization or not. A majority of scholars-many of them refugees from Nazi Germany in the United States - answered this question in the affirmative. Consequently, the prosecution built its case on the premise that the defendants betrayed the best interests of the German nation by veering off the Western liberal tradition.

The thesis in itself is convincing, insofar as it projects the American perspective on the trials. This caveat exposes a structural crack in Priemel's argumentation. Priemel argues against the notion that the Nuremberg was essentially an American project-the case typically made by the defense council. Yet the facts that Priemel cites undermine his conclusion. As he writes on page 71, "between the four Allies, the US were now firmly in the driver's seat," and again on page 222, "the NMT functioned very much like American courts." The US delegation at the IMT was nearly as large as the other three combined and many a legal innovation were American. Major figures in the Nazi German leadership were in US and British custody. The Americans toyed with the idea of staging a trial all by themselves, but eventually opted for an international tribunal in the spirit of wartime cooperation. By the same token, with the Cold War in full swing, the United States made a conscious decision to carry out the subsequent trials singlehandedly.

The Soviets, as Priemel attests, had a threefold agenda at IMT: to condemn Hitler's regime, to extract reparations, and to conceal their own unsavory deeds such as the Secret Protocol to the 1939 Molotov-Ribbentrop Pact. The Soviets were not the only one whose reading of German history differed from that of the Americans. The French, too, appeared to be primarily interested in checking the German aggression once and for all. In effect, these two delegations made a cause for Germany's foretold derogation rather than divergence The British, for their part, though not in opposition to the American baseline, were preoccupied with the legal aspect of the IMT. The four opening statements were complimentary, except in those parts that contradicted each other. 
There are a few other discursive threads in Priemel's book one may take issue with. Priemel construes the Nuremberg trials as a quintessential example of transitional justice, from dictatorship to democracy and from the Nazi war of extermination into the Cold War. There is an unintentional element of circular logic in Priemel designating it as transitional proceedings first and then arguing that in this very capacity the Nuremberg served as both the subject and object of history-making. A larger issue that the Nuremberg trials had bequeathed us is whether history didactics belong in a court of law. Priemel's unequivocal yes represents one side in an ongoing debate.

The few problems with Priemel's interpretation put aside, The Betrayal is a remarkable work of scholarship. Priemel delivers on his promise to produce a truly comprehensive history of Nuremberg. Despite the ideological divide, the four delegations tacitly agreed that prosecution of major Nazi war criminals should entail a rehabilitative element, yet all defendants should be convicted in the end. On certain issues, such as linking slave labor to the Nazi war of aggression, the Soviets and the Americans saw eye to eye. When it comes to the Nazi mass murder of the Jews, the Soviet exposé proved to be the most detailed. The gruesome atrocities perpetrated by some of the defendants did not match up to their physical appearance, though. Legal teams and the general public alike were disappointed to see in the dock non-descript individuals rather than proud Aryans they claimed to be. The defense council did not try to negate the crimes committed by their clients, using such strategies as evoking non-retroactivity and superior orders. Another popular tactic was shifting blame onto the deceased Nazi leaders. Thus, Hitler's name was mentioned some 12,000 times during the IMT. At the end of the day, the defense lawyers were more or less satisfied with the verdict. The double concept of conspiracy and aggressive war, central to the American approach, obviously did not work very well. Despite this and other shortcoming, the IMT was nevertheless a success. Priemel believes the prosecution made a convincing case, whereas the judges' backstage compromises never became public knowledge. Most crucial, the IMT made it virtually impossible for ordinary Germans to claim ignorance of the mass crimes committed in their name.

None of the Allies showed much enthusiasm for a second IMT. The US military weighed in on the internal debate, expressing a preference for war crimes trials in the American zone of occupation. By the time the IMT pronounced its verdict on October 1, 1946, working together with the Soviets was no longer in the cards. The newly appointed chief prosecutor Telford Taylor identified several categories of defendants, specifically within the industrial circles, the SS, the police, and the military. While the focus of the subsequent trials was narrowed down, Priemel argues that their overarching objective became more ambitious, namely to explain the workings of the Nazi regime. Some of the trials never got off the ground due to lack of proof, interest, and/or star defendants, for example the destruction of Warsaw or the Reich Main Security Office (RSHA). Among those trials that did take place, Taylor and his staff prioritized IG Farben, Krupp, Ministries, and High Command. As the medical experiments on humans made for a strong impact in the IMT, Taylor decided to start off with the so-called Doctors' case. The Medical Case promised to be an easy and quick trial with convictions all assured. When it comes to the professed goal of making the historical record straight, the didactical value inbuilt in this and other trials did not serve the purpose. To give just one example, the emphasis put on medical experiments downplayed the significance of the Nazi euthanasia program. As Priemel speculates, it had to do in part with the delicate issue of international eugenics-accepted as science during the interwar period, also in America-versus German racial hygiene. What the prosecution sought was metaphor, linking the men in the dock to the Nazi regime via their professional affiliations, thus underlining the German divergence thesis. The Cold War punched further holes in the historical master narrative, as illustrated most potently by the High Command trial. The October 1948 verdict occurred in the midst of the Berlin blockade and preceded the establishment of West Germany by seven months. By that time, it was already the Soviets who gained the status of a chief villain.

From the perspective of Holocaust studies, one of the most important cases was that of the Einsatzgruppen. Counterintuitively, Justice Robert Jackson did not make the SS case a centerpiece of the IMT. Priemel explains that, ironically, it did not fit well into the historical narrative Jackson was building. So overwhelming was the evidence of mass murder in the shape of notorious Einsatzgruppen reports that it nearly seemed lacking in complexity and storyline. Neither did Case 9 contribute much to the legal analysis of genocide. By making a case for pathology of 
the SS leadership, the prosecution engaged in oversimplification. Furthermore, it unwittingly marginalized other Reich agencies. The closer the defendant might be tied up to Himmler's SS, the more likely was a death penalty (in many cases subsequently commuted to life imprisonment and eventually early release). Priemel concludes that, on balance, the SS defendants fared worse than others in the NMT, yet better than expected at the outset of the trials.

The evidence of Nazi criminality that emerged from the Nuremberg has long been superseded. There is no doubt, however, that Germany's path after 1945 might have been different without it. I fully share in Priemel's conclusion that no story of political reconstruction of Germany is possible without a reference to the Nuremberg precedent. The Betrayal is a superbly researched and argued book on its way to becoming a standard work. 